\title{
Did plate tectonics control the generic diversity of Jurassic brachiopods? One point of view
}

\author{
Dmitry A. Ruban ${ }^{1,2}$ \\ ${ }^{1}$ Cherepovets State University, Sovetskiy Avenue 10, Cherepovets, Vologda Region, 162600, Russia \\ ${ }^{2}$ postal address: P.O. Box 7333, Rostov-na-Donu, 344056, Russia \\ e-mail: ruban-d@mail.ru
}

\begin{abstract}
Possible plate tectonic controls on faunal diversity dynamics have been discussed in the geological literature for around 50 years. The new model of plate tectonic processes is here linked to Jurassic generic diversity (simple a-diversity) of brachiopods. This comparison offers three observations, four hypotheses and three unresolved issues. Most importantly, changes in the global plate root mean square speed coincided with brachiopod diversity dynamics, which can be explained hypothetically by either environmental disturbance triggered by more active plate motion or activity of any process (such as eustasy) tied to plate tectonic mechanisms and with an impact on marine benthic communities. It is also established that global generic diversity dynamics of brachiopods during the Jurassic coincided with the regional picture as established for the Northern Caucasus and the Swiss Jura Alps; this coincidence is difficult to explain with regard to plate tectonics. These and other speculative considerations do not clarify the role of the plate tectonic factor in Jurassic generic diversity dynamics of brachiopods, and, thus, they indicate important issues for further research.
\end{abstract}

Key words: Brachiopoda, diversity dynamics, global sea level, lithospheric plates, mass extinction, Northern Caucasus, Swiss Jura Mountains

\section{Introduction}

Plate tectonics has remained essential geological process that is responsible, either directly or indirectly, for the majority of changes on and beneath the Earth's surface. Soon after this process was established, it was suggested plate tectonics was a significant factor of biotic evolution and, particularly, in changes of biodiversity. The most important contributions to this issue were those of Valentine \& Moores $(1970,1972)$ and, subsequently, by Hallam (1981). Recently, Ruban (2010a, 2013) has considered plate tectonics among factors underlying Palaeozoic biotic radiations. There have also been a few important case studies on this issue such as the ones by Knox (1980), Smith \& Tipper (1986) and Leprieur et al. (2016). New studies by Zaffos et al.
(2017) stressed once again the role of plate tectonics in Phanerozoic diversity changes; with publication of their paper, the research agenda has returned to the beginning of the 1970s when Valentine \& Moores $(1970,1972)$ published their famous works. New plate tectonic reconstructions and new diversity curves should be considered, as well as palaeontological data on particular fossil groups and from particular regions. Interpretations of previously accumulated information appear to be important, as are data from field-, collection- or model-based studies.

Brachiopods were important marine invertebrates that evolved throughout the entire Phanerozoic (Jones, 2012; Carlson, 2016; Jain, 2017). The number of genera fluctuated, being punctuated by several mass extinctions (Curry \& Brunton, 2007). 
The controls of this diversity dynamics are yet to be fully understood, and it cannot be excluded that plate tectonics was one of the most important controls. The new-generation plate tectonic reconstructions that differ from previous models by both precision and advanced approach (Seton et al., 2012; Matthews et al., 2016) allow new insights into the understanding of the possible plate tectonic control of brachiopod generic diversity (a simple form of a-diversity). The present paper focuses on the Jurassic interval of brachiopod evolution and aims to make simple observations first, to specify hypotheses, and to outline unresolved questions for future research.

\section{Global-scale observations and relevant hypotheses}

\subsection{Conceptual and methodological remarks}

Initially, Valentine \& Moores (1970) emphasised the role of continental assemblies and fragmentations as triggers of biodiversity changes. Researchers also established that particular tectonic events such as the opening of the Hispanic Corridor during the Early Jurassic had an impact on the evolution of marine fauna and, particularly, brachiopods (Riccardi, 1991; Hallam, 1996; Aberhan, 2001, 2002; Manceñido, 2002; Sha, 2002; Arias, 2006; Porter et al., 2013; Baeza-Carratalá et al., 2017). According to Zaffos et al. (2017), plate tectonics impacted biodiversity via fragmentation of the continental crust which facilitated an increase in the number of taxa.

The new-generation plate tectonic reconstructions proposed by Seton et al. (2012), subsequently updated by Matthews et al. (2016), permit judgements of changes in three main parameters, namely the number of lithospheric plates, the ratio between relatively small and relatively large plates and the global plate root mean square (RMS) speed. These can be compared directly with the Jurassic generic diversity dynamics of brachiopods (Curry \& Brunton, 2007). Indeed, simple coincidence (or its absence) of the curves cannot be considered as final proof of the presence (or absence) of plate tectonic control because the underlying causal mechanism should be found and explained. However, these observations are valuable for establishing lines for future investigations. In other words, these permit making new hypotheses that can be tested.

\subsection{Observations}

Jurassic brachiopod generic diversity underwent significant changes (Curry \& Brunton, 2007). It peaked in the Pliensbachian; then there was a minor, albeit long, diversity lowstand followed by rapid diversification that culminated during the Bathonian; a gradual decrease in the number of genera lasted until the end of the period (Fig. 1). The Toarcian-Aalenian diversity minimum can be explained by the influence of the early Toarcian mass extinction (Hallam, 1986; Little \& Benton,
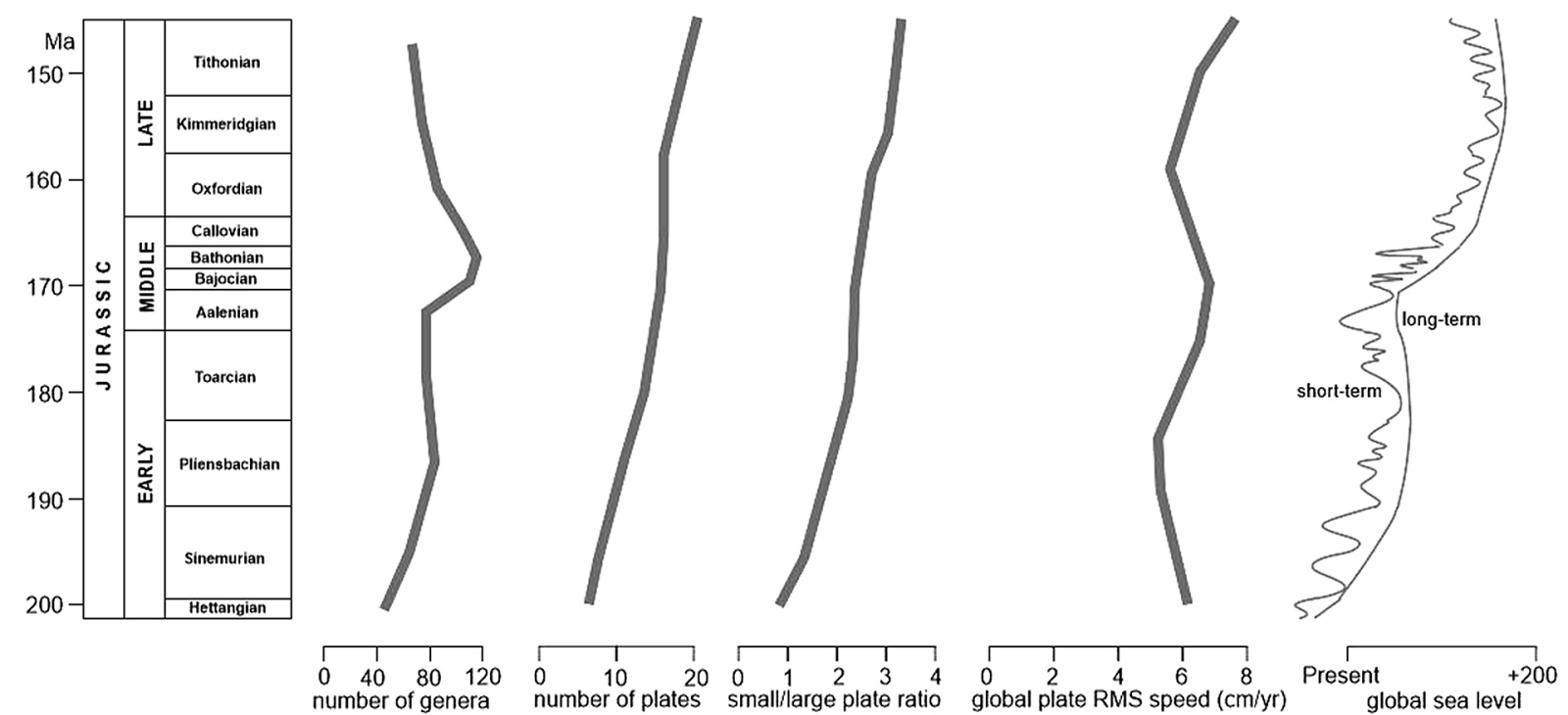

Fig. 1. Global Jurassic brachiopod diversity dynamics (after Curry \& Brunton, 2007) in the light of tectonic processes (curves adapted from Matthews et al., 2016) and eustatic changes (curve adapted from Haq \& Al-Qahtani, 2005; see also Ruban, 2015). The Jurassic chronostratigraphy follows Ogg et al. (2016; see www.stratigraphy.org for updates). 
1995; Harries \& Little, 1999; Wignall et al., 2005; Caswell et al., 2009; Baeza-Carratalá et al., 2016, 2017, 2018; Vörös et al., 2016; Caswell \& Frid, 2017; Ruban, 2018). However, it is questionable whether the mass extinction was the sole cause of such a long diversity lowstand; probably, some other factor(s) was (were) also responsible for the latter. Generally, the Jurassic generic diversity dynamics of brachiopods can be described as two large cycles, namely the Hettangian-Toarcian cycle and the Aalenian-Tithonian cycle. Although differences in the duration (in myr) of stages may explain some diversity patterns (e.g., number of genera too low in the Hettangian), the influence of this factor was unimportant because three Early Jurassic stages and all Late Jurassic stages were of comparable duration (Ogg et al., 2016) and the shortest Middle Jurassic stages were characterised by significant diversity (Fig. 1).

The number of lithospheric plates increased (and duplicated) through the Jurassic, and their size became smaller (Matthews et al., 2016). These patterns do not demonstrate any coincidence with brachiopod generic diversity dynamics (Observation 1 - Fig. 1). In contrast, the global plate RMS speed changed cyclically (Matthews et al., 2016) similarly to Jurassic brachiopod generic diversity dynamics, although their coincidence was peculiar (Observation 2 - Fig. 1). Increases in global plate RMS speed during the Toarcian-Aalenian and Kimmeridgian-Tithonian coincided with diversity decreases. In contrast, lower speeds during the HettangianPliensbachian and Bajocian-Callovian coincided with intervals of relatively high brachiopod diversity.

\subsection{Hypotheses and unresolved questions}

Observation 1 means that the tectonically induced fragmentation of the palaeospace and relevant multiplication of habitats, which both are well reflected by palaeobiogeographical differentiation, increased during the Jurassic (Westermann, 2000), did not facilitate brachiopod radiation throughout the period (Hypothesis 1). Apparently, the mechanism outlined by Zaffos et al. (2017) did not work in the case of Jurassic brachiopods.

Indeed, Observation 2 is astonishing. One would assume that more rapid plate motion (especially coinciding with a relatively high number and the small size of plates as in the case of the Jurassic) led to active faunal mixing and, thus, contributed to diversification. But the observed coincidence implies something opposite (Fig. 1). If this coincidence reflects the true (!) relationship of the patterns, two explanations are possible. First, the greater global plate RMS speed disturbed marine environments and led to stress among benthic fossil communities (Hypothesis 2). Secondly, the higher global plate RMS speed and/or related tectonic processes triggered any process that was important for brachiopod evolution, and the most likely process of this kind was eustasy (Hypothesis 3).

The current state of knowledge permits a preliminary verification of Hypothesis 3. The modern version of the eustatic curve proposed by Haq \& Al-Qahtani (2005), who updated an earlier reconstruction by Haq et al. (1987), shows two global sea level cycles during the Jurassic, namely the Hettangian-Aalenian and Bajocian-Tithonian cycles (Fig. 1 ). These correspond to changes in global plate RMS speed, as well as to cycles of brachiopod generic diversity dynamics. However, this correspondence is only partial. For instance, the Bajocian-Kimmeridgian global sea level rise coincided with both acceleration and reduction in global plate RMS speed, as well as to increase and then decrease in brachiopod diversity (Fig. 1). It is enigmatic which mechanism would link changes in global plate RMS speed and global sea level (Unresolved Question 1). Moreover, it still remains unclear how correct the curve proposed by Haq \& Al-Qahtani (2005) is. Some evidence that questions the accuracy of this curve and its predecessors is available (Hallam, 1988, 2001; Ruban \& Sallam, 2016; see also discussions in Ruban, 2015, 2016). However, Hypothesis 3 cannot be fully rejected. For instance, it is evident that the Hettangian-Aalenian and Bajocian-Tithonian cycles can be established on the curve described by global plate RMS speed and global sea level changes. In both cases, the reduction-acceleration of speed occurred prior to the rise-fall of eustasy. If a mechanism to explain such coincidence could be found, it would be possible to relate these processes to diversity dynamics (Unresolved Question 2).

\section{Regional perspective}

Two representative sets of regional palaeontological data have to be considered for the purposes of the present paper. The first region is the Northern Caucasus where stage-by-stage generic diversity dynamics was reconstructed by Ruban (2010b, 2011), and the second region is the Swiss Jura Mountains, for which updated palaeontological information (Sulser, 2016) permits the same reconstruction. These regions were located along the northern periphery of the Neo-Tethys Ocean. 

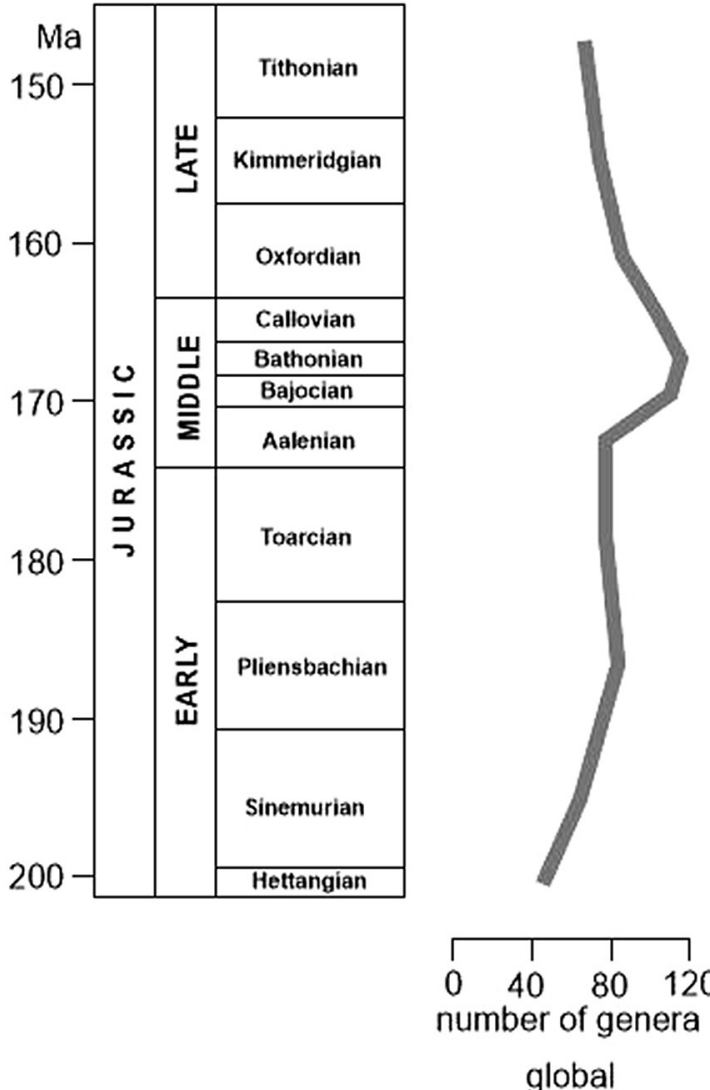
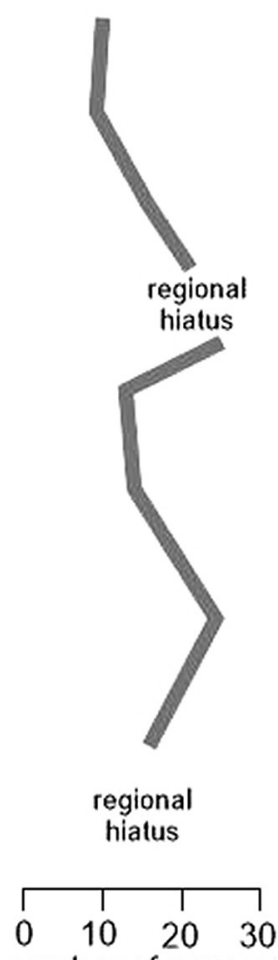

number of genera

\section{Northern Caucasus Swiss Jura Mountains}

Fig. 2. Regional Jurassic brachiopod diversity dynamics (Northern Caucasus; after Ruban, 2010b, 2011; Swiss Jura Mountains; calculated by the author using data supplied by Sulser, 2016). The Jurassic chronostratigraphy follows Ogg et al. (2016; see www.stratigraphy.org for updates); the global diversity curve is from Curry \& Brunton (2007).

The generic diversity dynamics in both of these regions is similar, and it also closely resembles global dynamics (Observation 3; Fig. 2). The only exception is the Oxfordian diversification in the Swiss Jura Mountains that should be explained by sampling effect (i.e., by excessive emphasis during earlier palaeontological research of Oxfordian successions) or regionally specific palaeoenvironments. From this similarity it follows that changes in the number of brachiopod genera in these two regions reflect global diversity dynamics of these organisms. Observation 3 enables the following hypothesis: if plate tectonics controlled global Jurassic generic brachiopod diversity, it was also responsible for regional (basin-level) changes of this diversity (Hypothesis 4).

The Northern Caucasus was located in a setting that was tectonically very active and characterised by development and interaction of island arcs and back-arc basins near a major, planet-scale subduction zone (Golonka, 2004; Ruban, 2006, 2010c). The Swiss Jura Mountains were located in a "calmer" and less restricted setting, but the Jurassic evolution of this region was also marked by some kind of tectonic activity (Sommaruga, 1997; Golonka, 2004; Pfiffner, 2014; Strasser et al., 2015). With regard to the above, it appears unexpected that regional diversity dynamics of brachiopods did not differ between these regions and that they did not differ significantly from global diversity dynamics. Plate tectonic mechanisms cannot explain Observation 3 (Unresolved Question 3).

\section{Conclusions}

Taken together, the three observations, four hypotheses, and three unresolved questions proposed in this brief note (see labels in the text above) imply significant uncertainty in our understanding of possible plate tectonic control of the generic diversity of Jurassic brachiopods in the light of current knowledge. However, the same observations, hypotheses, and unresolved questions can be used as important issues on the agenda for future investigations. These issues should be addressed adequately with larger sets of precise data and advanced conceptual and methodological approaches. It is also sensible 
to claim for comparison, integration, and theoretical treatment of new data, interpretations and models in order to highlight ways for future refinement of palaeobiological and geological research.

\section{Acknowledgements}

The author is grateful to two anonymous reviewers for constructive criticism and to N.M.M. Janssen (the Netherlands), W. Riegraf (Germany) and H. Sulser (Switzerland) for help with items of literature.

\section{References}

Aberhan, M., 2001. Bivalve palaeobiogeography and the Hispanic Corridor: Time of opening and effectiveness of a proto-Atlantic seaway. Palaeogeography, Palaeoclimatology, Palaeoecology 165, 375-394.

Aberhan, M., 2002. Opening of the Hispanic Corridor and Early Jurassic bivalve biodiversity. Geological Society Special Publication 194, 127-139.

Arias, C., 2006. Northern and Southern Hemispheres ostracod palaeobiogeography during the Early Jurassic: Possible migration routes. Palaeogeography, Palaeoclimatology, Palaeoecology 233, 63-95.

Baeza-Carratalá, J.F., García Joral, F. \& Tent-Manclús, J.E., 2016. Lower Jurassic brachiopods from the Ibero-Levantine Sector (Iberian Range): Faunal turnovers and critical bioevents. Journal of Iberian Geology 42, 355-369.

Baeza-Carratalá, J.F., Reolid, M. \& García Joral, F., 2017. New deep-water brachiopod resilient assemblage from the South-Iberian Palaeomargin (Western Tethys) and its significance for the brachiopod adaptive strategies around the Early Toarcian Mass Extinction Event. Bulletin of Geosciences 92, 233-256.

Baeza-Carratalá, J.F., García Joral, F., Goy, A. \& Tent-Manclús, J.E., 2018. Arab-Madagascaran brachiopod dispersal along the North-Gondwana paleomargin towards the Western Tethys Ocean during the Early Toarcian (Jurassic). Palaeogeography, Palaeoclimatology, Palaeoecology 490, 252-268.

Carlson, S.J., 2016. The Evolution of Brachiopoda. Annual Review of Earth and Planetary Sciences 44, 409-438.

Caswell, B.A. \& Frid, C.L.J., 2017. Marine ecosystem resilience during extreme deoxygenation: the Early Jurassic oceanic anoxic event. Oecologia 183, 275-290.

Caswell, B.A., Coe, A.L. \& Cohen, A.S., 2009. New range data for marine invertebrate species across the early Toarcian (Early Jurassic) mass extinction. Journal of the Geological Society 166, 859-872.

Curry, G.B. \& Brunton, C.H.C., 2007. Stratigraphic distribution of brachiopods. In: Selden, P.A. (Ed.), Treatise on Invertebrate Paleontology. Part H. Brachiopoda. Revised. Vol. 6. Geological Society of America, University of Kansas, Boulder and Lawrence, pp. 2901-3081.
Golonka, J., 2004. Plate tectonic evolution of the southern margin of Eurasia in the Mesozoic and Cenozoic. Tectonophysics 381, 235-273.

Hallam, A., 1981. Plate tectonics, biogeography and evolution. Nature 293, 31-32.

Hallam, A., 1986. The Pliensbachian and Tithonian extinction events. Nature 319, 765-768.

Hallam, A., 1988. A re-evaluation of Jurassic eustasy in the light of new data and the revised Exxon curve. In: Wilgus, C.K., Hastings, B.S., Kendall, C.G.St.C., Posamentier, H.W., Ross, C.A. \& Van Wagoner, J.C. (Eds): Sea-Level Changes - An Integrated Approach. SEPM Special Publication 42, pp. 261-273.

Hallam, A., 1996. Recovery of the marine fauna in Europe after the end-Triassic and early Toarcian mass extinctions. Geological Society Special Publication 102, 231-236.

Hallam, A., 2001. A review of the broad pattern of Jurassic sea-level changes and their possible causes in the light of current knowledge. Palaeogeography, Palaeoclimatology, Palaeoecology 167, 23-37.

Haq, B.U. \& Al-Qahtani, A.M., 2005. Phanerozoic cycles of sea-level change on the Arabian Platform. GeoArabia 10, 127-160.

Haq, B.U., Hardenbol, J. \& Vail, P.R., 1987. Chronology of Fluctuating Sea Levels Since the Triassic. Science 235, 1156-1167.

Harries, P.J. \& Little, C.T.S., 1999. The early Toarcian (Early Jurassic) and the Cenomanian-Turonian (Late Cretaceous) mass extinctions: similarities and contrasts. Palaeogeography, Palaeoclimatology, Palaeoecology 154, 39-66.

Jain, S., 2017. Fundamentals of Invertebrate Palaeontology. Macrofossils. Springer, New Delhi, 405 pp.

Jones, R.W., 2012. Applied Palaeontology. Cambridge University Press, Cambridge, $434 \mathrm{pp}$.

Knox, G.A., 1980. Plate tectonics and the evolution of intertidal and shallow-water benthic biotic distribution patterns of the southwest Pacific. Palaeogeography, Palaeoclimatology, Palaeoecology 31, 267-297.

Leprieur, F., Descombes, P., Gaboriau, T., Cowman, P.F., Parravicini, V., Kulbicki, M., Melian, C.J., De Santana, C.N., Heine, C., Mouillot, D., Bellwood, D.R. \& Pellissier, L., 2016. Plate tectonics drive tropical reef biodiversity dynamics . Nature Communications 7, 11461.

Little, C.T.S. \& Benton, M.J., 1995. Early Jurassic mass extinction: A global long-term event. Geology 23, 495498.

Manceñido, M.O., 2002. Paleobiogeography of Mesozoic brachiopod faunas from Andean-Patagonian areas in a global context. Geobios 35 (supplement), 176-192.

Matthews, K.J., Maloney, K.T., Zahirovic, S., Williams, S.E., Seton, M. \& Müller, R.D., 2016. Global plate boundary evolution and kinematics since the late Paleozoic. Global and Planetary Change 146, 226-250.

Ogg, J.G., Ogg, G.M. \& Gradstein, F.M., 2016. A Concise Geologic Time Scale 2016. Elsevier, Amsterdam.

Pfiffner, O.A., 2014. Geology of the Alps. Wiley-Blackwell, Chichester, $376 \mathrm{pp}$.

Porter, S.J., Selby, D., Suzuki, K. \& Gröcke, D., 2013. Opening of a trans-Pangaean marine corridor dur- 
ing the Early Jurassic: Insights from osmium isotopes across the Sinemurian-Pliensbachian GSSP, Robin Hood's Bay, UK. Palaeogeography, Palaeoclimatology, Palaeoecology 375, 50-58.

Riccardi, A.C., 1991. Jurassic and cretaceous marine connections between the Southeast Pacific and Tethys. Palaeogeography, Palaeoclimatology, Palaeoecology 87, 155-189.

Ruban, D.A., 2006. The Palaeogeographic Outlines of the Caucasus in the Jurassic: The Caucasian Sea and the Neotethys Ocean. Geološki anali Balkanskoga poluostroa 67, 1-11.

Ruban, D.A., 2010a. Palaeoenvironmental setting (glaciations, sea level, and plate tectonics) of Palaeozoic major radiations in the marine realm. Annales de Paléontologie 96, 143-158.

Ruban, D.A., 2010b. The Permian/Triassic mass extinction among brachiopods in the Northern Caucasus (northern Palaeo-Tethys): A tentative assessment. Geobios 43, 355-363.

Ruban, D.A., 2010c. Spatio-temporal patterns of the major Bathonian (Middle Jurassic) hiatus in the Greater Caucasus Basin (Northern Neo-Tethys Ocean) and its enigmatic origin. GeoActa 9, 21-30.

Ruban, D.A., 2011. Diversity dynamics of Callovian-Albian brachiopods in the Northern Caucasus (northern Neo-Tethys) and a Jurassic/Cretaceous mass extinction. Paleontological Research 15, 154-167.

Ruban, D.A., 2013. Was there more space in the late Early Devonian for marine biodiversity to peak than in the early Late Ordovician? A brief note. Geološki anali Balkanskoga poluostrva 74, 1-8.

Ruban, D.A., 2015. Mesozoic long-term eustatic cycles and their uncertain hierarchy. Geoscience Frontiers 6, 503-511.

Ruban, D.A., 2016. A "chaos" of Phanerozoic eustatic curves. Journal of African Earth Sciences 116, 225-232.

Ruban, D.A., 2018. Episodic events in long-term geological processes: A new classification and its applications. Geoscience Frontiers 9, 377-389.

Ruban, D.A. \& Sallam, E.S., 2016. Bajocian-Bathonian (Middle Jurassic) sea-level changes in northeastern Egypt: Synthesis and further implications. Journal of African Earth Sciences 120, 181-185.

Seton, M., Müller, R.D., Zahirovic, S., Gaina, C., Torsvik, T., Shephard, G., Talsma, G., Gurnis, M., Turner, M., Maush, S. \& Chandler, M. 2012. Global conti- nental and ocean basin reconstructions since $200 \mathrm{Ma}$. Earth-Science Reviews 113, 212-270.

Sha, J., 2002. Hispanic corridor formed as early as Hettangian: On the basis of bivalve fossils. Chinese Science Bulletin 47, 414-417.

Smith, P.L. \& Tipper, H.W., 1986. Plate tectonics and paleobiogeography: early Jurassic (Pliensbachian) endemism and diversity (North America). Palaios 1, 399-412.

Sommaruga, A., 1997. Geology of the Central Jura and the Molasse Basin: New insight into an evaporite-based foreland fold and thrust belt. Mémoire de la société neuachâteloise des sciences naturelles 12, 1-176.

Strasser, A., Pittet, B. \& Hug, W., 2015. Palaeogeography of a shallow carbonate platform: The case of the Middle to Late Oxfordian in the Swiss Jura Mountains. Journal of Palaeogeography 4, 251-268.

Sulser, H., 2016. Die fossilen Brachiopoden der Schweiz und der umliegenden Gebiete. Paläontologisches Institut und Museum der Universität Zürich, Zürich, 454 pp.

Valentine, J.W. \& Moores, E.M., 1970. Plate-tectonic regulation of faunal diversity and sea level: A model. $\mathrm{Na}$ ture 228, 657-659.

Valentine, J.W. \& Moores, E.M., 1972. Global Tectonics and the Fossil Record. Journal of Geology 80, 167-184.

Vörös, A., Kocsis, Á.T. \& Pälfy, J., 2016. Demise of the last two spire-bearing brachiopod orders (Spiriferinida and Athyridida) at the Toarcian (Early Jurassic) extinction event. Palaeogeography, Palaeoclimatology, Palaeoecology 457, 233-241.

Westermann, G.E.G., 2000. Marine faunal realms of the Mesozoic: review and revision under the new guidelines for biogeographic classification and nomenclature. Palaeogeography, Palaeoclimatology, Palaeoecology 163, 49-68.

Wignall, P.B., Newton, R.J. \& Little, C.T.S., 2005. The timing of paleoenvironmental change and cause-andeffect relationships during the Early Jurassic mass extinction in Europe. American Journal of Science 305, 1014-1032.

Zaffos, A., Finnegan, S. \& Peters, S.E., 2017. Plate tectonic regulation of global marine animal diversity. Proceedings of the National Academy of Sciences of the United States of America 114, 5653-5658.

Manuscript submitted 30 July 2017 Revision accepted 8 January 2018 